\title{
The palaeoenvironmental development of the northeastern Vietnamese Mekong River Delta since the mid Holocene
}

The Holocene

20(8) 1257-1268

(C) The Author(s) 2010

Reprints and permission:

sagepub.co.uk/journalsPermissions.nav DOI: I0.1 I77/09596836/0374884

http://hol.sagepub.com

(\$)SAGE

\author{
Ulrike Proske, ',2 Till J.J. Hanebuth, ${ }^{1,2}$ Hermann Behling, ${ }^{3}$ \\ Van Lap Nguyen, ${ }^{4}$ Thi Kim Oanh Ta ${ }^{4}$ and Bui Phat Diem ${ }^{5}$
}

\begin{abstract}
Three radiocarbon-dated sediment cores from the northeastern Vietnamese Mekong River Delta have been analysed with a multiproxy approach (grain size, pollen and spores, macro-charcoal, carbon content) to unravel the palaeoenvironmental history of the region since the mid Holocene. During the midHolocene sea-level highstand a diverse, zoned and widespread mangrove belt (dominated by Rhizophora) covered the extended tidal flats. The subsequent regression and coeval delta progradation led to the rapid development of a back-mangrove community dominated by Ceriops and Bruguiera but also represented locally by e.g. Kandelia, Excoecaria and Phoenix. Along rivers this community seems to have endured even when the adjoining floodplain had already shifted to freshwater vegetation. Generally this freshwater vegetation has a strong swamp signature but locally Arecaceae, Fabaceae, Moraceae/ Urticaceae and Myrsinaceae are important and mirror the geomorphological diversity of the delta plain. The macro-charcoal record implies that natural burning of vegetation occurred throughout the records, however, the occurrence of the highest amounts of macro-charcoal particles is linked with modern human activity.
\end{abstract}

\section{Keywords}

Holocene, macro-charcoal, modern human impact, palaeoenvironment, pollen, Vietnamese Mekong River Delta

\section{Introduction}

The Mekong River Delta in southern Vietnam and southern Cambodia is formed by the Mekong and Bassac River systems and extends over an area of $62520 \mathrm{~km}^{2}$ today (Nguyen et al., 2000). The oldest sediments, which are linked to the modern delta body, accumulated in the early mid-Holocene at about 8000 calibrated years before present (cal. yr BP) (Tamura et al., 2009) preceding the mid-Holocene sea-level highstand in the South China Sea. In the case of the Mekong River Delta (MRD, in the following used as abbreviation for the Vietnamese part of the Mekong River Delta unless stated otherwise, the term 'delta' refers the Cambodian and Vietnamese Mekong River Delta) area, the highstand of c. 2.5 to $4.5 \mathrm{~m}$ above present sea level lasted from $c .6000$ to $5000 \mathrm{cal}$. yr BP (Ta et al., 2002a, b). In this phase the coastline was located in modern southern Cambodia (Nguyen et al., 2000; Tamura et al., 2009) and is generally referred to as marking the most landward margin of the delta body (Woodroffe et al., 2006). Pollen records as well as peat horizons imply that a broad mangrove swamp covered the coastal zone in the mid Holocene (Penny, 2006, 2008; Tamura et al., 2009). The subsequent regression together with a large sediment discharge (since $3000 \mathrm{cal}$. yr BP: $144 \pm 36 \times 10^{6} \mathrm{t} / \mathrm{yr}$, Ta et al., 2002b) enabled the fast progradation of the MRD (Nguyen et al., 2000).

Today the delta is one of the megadeltas in Asia that is intensively used for agriculture, forestry and fishery by 17 million people (Mekong River Commission, 2005). The agricultural use of the delta plain has a long history but the large-scale, intensified rice farming by the Vietnamese, which form the majority of the population in the MRD today, started in the seventeenth century (Biggs, 2003). Together with Chinese settlers Vietnamese people started to migrate into the relatively sparsely populated delta area and expanded the rice paddies during the 1600s (Biggs, 2003; Biggs et al., 2009). Until the eighteenth century, however, agriculture centred along large rivers and creeks (Biggs, 2003). With the major canal excavations in the eighteenth and nineteenth centuries the water balance on the MRD plain became easier to control and opened new areas for settlement and agriculture (Biggs, 2003; Kono, 2001). Some marginal swamp areas such as the Dong Thap Muoi (or Plain of Reeds, Figure 1) remained widely uninhabited until after 1975 when further canal excavations promoted the

\footnotetext{
'University of Bremen, Germany

${ }^{2}$ MARUM - Centre for Marine Environmental Sciences, University of Bremen, Germany

${ }^{3}$ University of Göttingen, Germany

${ }^{4}$ Vietnamese Academy of Science and Technology, Vietnam

${ }^{5}$ Provincial Museum Long An, Vietnam
}

Received 23 January 2010; revised manuscript accepted I2 May 2010

Corresponding author:

Ulrike Proske, Faculty of Geosciences, University of Bremen, Klagenfurter Strasse 2, 28359 Bremen, Germany

Email: uproske@uni-bremen.de 
development of extensive rice cultivation (Kono, 2001; Nguyen et al., 1998; Tanaka, 2001).

The palaeoenvironmental development of the MRD has been the focus of only few studies so far. In the western and southern parts of the MRD, the change from mid-Holocene mangrove to late-Holocene freshwater vegetation varied temporally and spatially (Nguyen, 1993). According to Nguyen (1993) the major factors for this variance are local differences in topography, water balance and substrate. In the northeastern MRD, however, the palynological signal in the sedimentary record implies that mangroves seem to have vanished relatively abruptly (Proske et al., 2010). However, some saltwater-tolerant vegetation, in particular back-mangrove communities, could have prevailed longer in the area mainly along major rivers (Fujimoto et al., 2008). During the late Holocene, indigenous freshwater vegetation was at least in parts dominated by a tropical forest as the discovery of large tree stumps implies (Sterling et al., 2006). This forest would certainly resemble the forest types adjoining the modern delta: a mix of evergreen, semi-evergreen (dominated by Lagerstroemia), deciduous and coastal forests that are often dominated by Dipterocarpaceae (Duc, 2006; Schmid, 1974, 1989; Sterling et al., 2006).

With the conversion of the land for large-scale occupation and agriculture the indigenous vegetation became restricted to very local patches (Tanaka, 2001). Besides the cultivated areas that are mainly covered by rice (Oryza sativa japonica), sugarcane (Saccharum officinarum), pineapple (Ananas comosus), coconut (Cocos nucifera) and banana (Musa $\times$ paradisiaca) (Hori, 2000), three main forms of natural vegetation remain in the modern MRD: freshwater swamp forest and freshwater grasslands (U Minh region, Plain of Reeds and Ha Tien Plain) as well as mangrove (along major parts of the coast) (Sterling et al., 2006).

An overview over the major relevant freshwater families and their habitat is given in Table 1. The modern freshwater swamp forests are most common in the Plain of Reeds where the permanently water-logged soils offer ideal conditions for the dominant tree Melaleuca cajuputi (Sterling et al., 2006). These forests are adjoined by swamps and grasslands that include grasses (particularly Echinochloa crus-galli, Eriochloa procera, Oryza rufipogon), sedges (mainly Cyperus elatus, Cyperus polystachos, Eleocharis dulcis), ferns (e.g. Marsilea minuta), aquatic plants (predominantly Nelumbium nelumbo, Nymphaea sp.) and Melaleuca leucodendron. On elevated areas (e.g. levees) Lagerstroemia speciosa, Ficus microcarpa, Elaeocarpus sp., Morinda persicifolia as well as Dipterocarpaceae can be found (Duc, 2006). Along major rivers smaller stands of e.g. Barringtonia acutangula, Terminalia chabula, and Diospyros cambodiana are observed (Duc, 2006).

The composition of the mangrove community varies depending on the amount of freshwater input. An overview of mangrove genera and their appearance within the different zones of the mangrove forest is given in Table 2 (Hong 2000; Hong and San, 1993; Schmid, 1974; Tomlinson 1994). Generally, the estuarine successions are dominated by Sonneratia, Avicennia, Rhizophora, Ceriops, Bruguiera, Phoenix paludosa and the fern Acrostichum aureum but can additionally host Acanthus ilicifolius, Flagellaria indica, Melastoma polyanthum and Dalbergia candenatensis. (Hong, 2000; Hong and San, 1993). The saltwater successions are dominated by Sonneratia, Rhizophora, Xylocarpus, Ceriops, Avicennia, Excoecaria agallocha and Phoenix paludosa (Hong, 2000; Hong and San, 1993).
Table I. Freshwater genera

\begin{tabular}{|c|c|c|c|c|c|c|c|c|c|c|}
\hline Family & Genus & $\mathrm{R} / \mathrm{E}$ & $\mathrm{F}$ & Sh & St & FS & Sat & Ap & $\mathrm{Aq}$ & An \\
\hline Alismataceae & Sagittaria & & & & & & & & $x$ & \\
\hline Arecaceae & $\begin{array}{l}\text { excl. Nypa \& } \\
\text { Phoenix }\end{array}$ & & $X$ & $X$ & & $X$ & & & & $X$ \\
\hline Asclepiaceae & - & & $\mathrm{X}$ & & $\mathrm{X}$ & & & & & \\
\hline Asteraceae & - & & $x$ & $x$ & & $\mathrm{X}$ & & & & \\
\hline Aquifoliaceae & Ilex & & $x$ & $x$ & & & & & & \\
\hline Burmanniaceae & Burmannia & & & & & $x$ & & & & \\
\hline Chenopodiaceae/ & - & & & & $\mathrm{X}$ & & & & & \\
\hline Amaranthaceae & & & & & & & & & & \\
\hline Combretaceae & - & & $\mathrm{X}$ & & & & & & & \\
\hline Cyperaceae & - & $\mathrm{X}$ & $\mathrm{X}$ & $x$ & $\mathrm{X}$ & $\mathrm{x}$ & & $\mathrm{X}$ & & \\
\hline Elaeocarpaceae & - & $x$ & $x$ & & & $x$ & & & & \\
\hline Euphorbiaceae & - & & $x$ & $x$ & & & $\mathrm{X}$ & $x$ & & \\
\hline Fabaceae & - & $x$ & $x$ & $x$ & $\mathrm{X}$ & $\mathrm{X}$ & $x$ & $x$ & & $\mathrm{x}$ \\
\hline Fagaceae & - & & $x$ & $x$ & & & & & & \\
\hline Melastomataceae & - & & $x$ & $x$ & $\mathrm{X}$ & $\mathrm{X}$ & & $\mathrm{X}$ & & \\
\hline Moraceae & - & & $x$ & $x$ & & $x$ & $x$ & & & \\
\hline Myrsinaceae & - & & $\mathrm{X}$ & $\mathrm{X}$ & & & & & & \\
\hline Myrtaceae & - & & $x$ & & & $x$ & & & & \\
\hline Orchidaceae & - & & 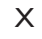 & & & $x$ & & & & \\
\hline Pandanaceae & Pandanus & & $x$ & & & $x$ & & & & $X$ \\
\hline Pinaceae & Pinus & & $x$ & & & & & & & \\
\hline Piperaceae & - & & $x$ & $\mathrm{X}$ & & & & & & \\
\hline Poaceae & - & $x$ & $x$ & $x$ & $\mathrm{X}$ & $x$ & $\mathrm{x}$ & $\mathrm{X}$ & & $\mathrm{X}$ \\
\hline Sapindaceae & - & & $\mathrm{X}$ & $\mathrm{X}$ & & & & & & \\
\hline Urticaceae & - & & $x$ & & & & & & & \\
\hline Azollaceae & Azolla & & & & & & & & $x$ & $\mathrm{X}$ \\
\hline Polypodiaceae & - & $\mathrm{X}$ & $\mathrm{X}$ & & & $\mathrm{X}$ & & & & \\
\hline Pteridaceae & Acrostichum & $\mathrm{X}$ & & & & & & & & \\
\hline
\end{tabular}

R/E, river/estuary; F, forest general; Sh, shrubland; St, steppe; FS, freshwater swamp; Sat, sandy terrace; Ap, alluvial plain; Aq, aquatic; An, anthropogenic.

This paper presents three sedimentary successions showing the palaeoenvironmental development of the northeastern MRD in the last $c .8000$ years. It also addresses the regional diversity of the vegetation and mangroves in particular and it documents the impact of modern human settlement on the regional environment.

\section{Study area}

The northeastern part of the MRD (Figure 1) is only elevated 0.5 to $1.5 \mathrm{~m}$ above modern sea level (Duc, 2006; Nguyen et al., 1998) which has consequences for the water balance, soil characteristics and thus vegetation. Generally the water balance in the delta is controlled by river discharge (varying seasonally with high discharges during the summer monsoon) and the tidal amplitude of 3.0-3.5 $\mathrm{m}$ in the South China Sea (Mekong River Commission, 2005). The delta area has an average annual precipitation of 1000 $2000 \mathrm{~mm}$ falling mainly between April and October (Nguyen et al., 1998) when the whole Mekong River basin is subjected to the summer monsoon (Hori, 2000). This rainfall together with excess river water causes up to a four-month long inundation in the northeastern part of the MRD (Hori, 2000).

\section{Material}

\section{Sediment core characteristics}

The sediment cores TD08-01 (TD), GD07-01 (GD) and TA07-01 (TA) have been hand-drilled (Edelmann and D-section auger) during two campaigns to Long An province, northeastern MRD in March 2007 and December 2008. 
Table 2. Mangrove genera

\begin{tabular}{|c|c|c|c|c|c|c|}
\hline Family & Genus & Seaward margin & Inner mangrove & Back mangrove & Landward edge & River/estuary \\
\hline Myrsinaceae & Aegiceras & $\mathrm{X}$ & & & & \\
\hline Sonneratiaceae & Sonneratia & $x$ & $x$ & & & \\
\hline Rhizophoraceae & Rhizophora & & $x$ & $x$ & & \\
\hline Acanthaceae & Acanthus & & $x$ & $x$ & & \\
\hline Avicenniaceae & Avicennia & & $x$ & $x$ & & \\
\hline \multirow[t]{2}{*}{ Rhizophoraceae } & Ceriops & & $x$ & & & \\
\hline & Bruguiera & & $x$ & $x$ & & \\
\hline Meliaceae & Xylocarpus & & $x$ & $x$ & & \\
\hline Rhizophoraceae & Kandelia & & & $x$ & & $x$ \\
\hline Sterculiaceae & Heritiera & & & $x$ & & \\
\hline \multirow[t]{2}{*}{ Euphorbiaceae } & Excoecaria & & & $x$ & & \\
\hline & Glochidion & & & $x$ & & \\
\hline Flagellariaceae & Flagellaria & & & $x$ & & \\
\hline Combretaceae & Lumnitzera & & & $x$ & & \\
\hline Araceae & Cryptocoryne & & & $x$ & $\mathrm{X}$ & \\
\hline Annonaceae & Annona & & & $x$ & $x$ & \\
\hline Flagellariaceae & Flagellaria & & & $x$ & $x$ & \\
\hline \multirow[t]{2}{*}{ Arecaceae } & Phoenix & & & & $x$ & \\
\hline & Nypa & & & & $x$ & $x$ \\
\hline Fabaceae & Dalbergia & & & & $x$ & \\
\hline Melastomataceae & Melastoma & & & & $x$ & \\
\hline Pteridaceae & Acrostichum & & & $\mathrm{x}$ & & $x$ \\
\hline
\end{tabular}
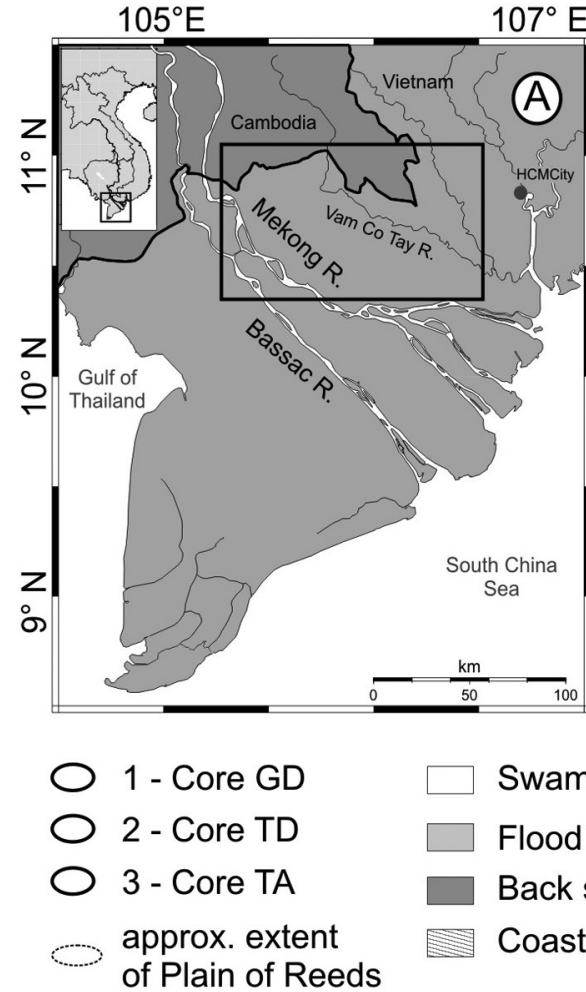

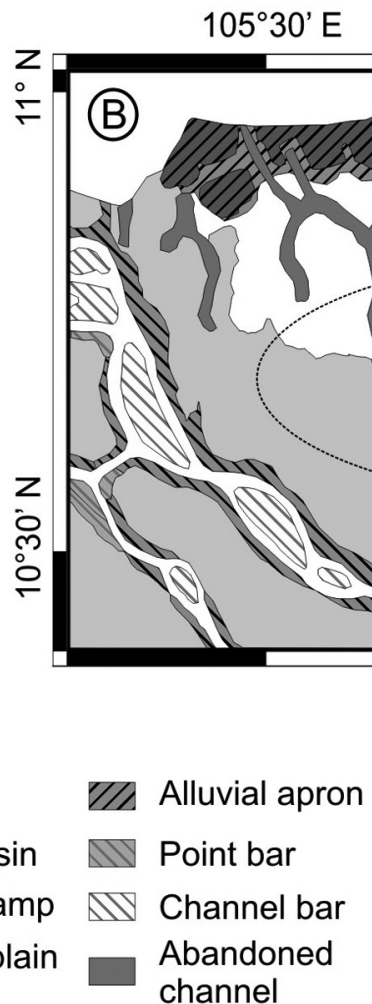
channel
Swamp

Flood basin

Back swamp

Coastal plain

Figure I. (A) The Vietnamese Mekong River Delta and adjacent areas with its two major rivers, the Bassac and the Mekong. The smaller inset map displays the position of the delta within mainland Southeast Asia. The black square marks the area shown in (B). (B) The facies distribution and geomorphological features in the study area according to Nguyen et al. (2000). The open circles show the coring locations of cores GD, TD and TA. The dashed circle outlines the approximate extent of the Plain of Reeds

Core TD. The drilling site $\left(10^{\circ} 39.731^{\prime} \mathrm{N}, 106^{\circ} 12.928^{\prime} \mathrm{E}\right.$, Thanh Hoa district) lies in a meander loop within the floodplain of the Vam Co Tay River in the Plain of Reeds (Figure 1B). The core top lies $c .0 .5$ to $1 \mathrm{~m}$ above modern sea level. The uppermost 29 $\mathrm{cm}$ consisting of hard clay were too compacted to be drilled with the D-section corer and had to be removed. The complete 516 $\mathrm{cm}$ long core consists of dark greyish brown to brownish and very dark grey mud (clay + silt) with few yellowish-red mottles at the top.

Core GD. The coring site $\left(10^{\circ} 40.216^{\prime} \mathrm{N}, 105^{\circ} 51.651^{\prime} \mathrm{E}\right.$, Tan Thanh district) is located in the central Plain of Reeds bordering a long channel (Figure 1B). The top of the core is $c .0 .5$ to $1 \mathrm{~m}$ above modern sea level. The $465 \mathrm{~cm}$ long core consists of dark grey to 
Table 3. Age data

\begin{tabular}{|c|c|c|c|c|c|c|}
\hline Core & $\begin{array}{l}\text { Sample }(\mathrm{cm} \\
\text { core depth) }\end{array}$ & $\begin{array}{l}\text { Uncalibrated age } \\
(\mathrm{yr})\end{array}$ & $\begin{array}{l}\text { Specific reservoir } \\
\text { correction } \Delta R\end{array}$ & 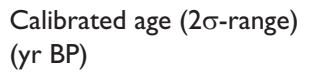 & Dated material & Lab. code \\
\hline TD & $132-134$ & $2775 \pm 35$ & - & $2790-2950$ & Plant remains & Poz-30916 \\
\hline \multirow[t]{4}{*}{ GD } & 80 & $5590 \pm 40$ & - & $6300-6440$ & Plant remains & Poz-30910 \\
\hline & 112 & $4650 \pm 40$ & - & $5310-5470$ & Plant remains & Poz-309II \\
\hline & 167 & $5570 \pm 35$ & - & $6290-6410$ & Plant remains & Poz-21312 \\
\hline & 213 & $6040 \pm 40$ & - & $6780-7000$ & Plant remains & Poz-21313 \\
\hline \multirow[t]{2}{*}{ TA } & 335 & $4420 \pm 35$ & $-70 \pm 30$ & $4440-4820$ & Carbonate shells & Poz-21507 \\
\hline & & & $-23 \pm 56$ & & & \\
\hline
\end{tabular}

greyish brown mud except for a sandy section from $\sim 170$ to $\sim 90$ $\mathrm{cm}$. From 380 to 360 and 130 to $0 \mathrm{~cm}$ numerous yellowish-reddish mottles and concretions occur.

Core TA. The drilling site $\left(10^{\circ} 31.432^{\prime} \mathrm{N}, 106^{\circ} 23.189^{\prime} \mathrm{E}\right)$ is close to the town Tan An, bordering a maize field in the vicinity of the Vam Co Tay River floodplain (Figure 1B). The core top lies c. 1.0 to $1.5 \mathrm{~m}$ above modern sea level. The $340 \mathrm{~cm}$ long core consists of brownish to greyish mud except for a dark grey to bluish sandy section between 340 and $196 \mathrm{~cm}$. From $238 \mathrm{~cm}$ to the top numerous brownish-yellow concretions and mottles occur.

\section{Methods}

\section{Sediment analysis}

Sediment samples were taken in the field based on the visual core description (TD: 86 samples ( $2 \mathrm{~cm}$ thickness), GD: 26 (5 cm thickness) and TA: 14 (5 cm thickness)). Additionally, material suitable for radiocarbon dating was extracted and stored separately. In the laboratory one-half of each sample was freeze-dried and c. $1 \mathrm{~g}$ was used for total carbon measurements (TC, LECO combustion). Only TC was measured since the detection of carbonate in organicrich sediments by LECO-combustion yields large errors. The rest of each sample was wet-sieved at $63 \mu \mathrm{m}$. Samples with a distinct portion $>63 \mu \mathrm{m}$ were further sieved at $125,250,500$ and $1000 \mu \mathrm{m}$.

\section{Radiocarbon dating}

Seven samples of selected organic fragments (wood/plant remains) or carbonate shells (Table 3) were submitted for radiocarbon dating at the Poznań Radiocarbon Laboratory, Poland. The calibration was accomplished by Calib version 5.0.1 (Stuiver and Reimer, 1993) using the terrestrial record for the organic fragments (intcal04) and the marine record for the shells (marine04). An ocean-specific, local reservoir effect based on two calibration points for southern Vietnam has been calculated in Calib and used for the calibration of the marine material (Table 3). However, since all the dated carbonate shells originate from shallow-water organisms, there are still some uncertainties in the local reservoir age. In the following the $2 \sigma$-range of all samples is used in order to account for the variance of the calibration curve in the covered time span (Table 3).

\section{Pollen, spore and charcoal analysis}

For pollen and spore analysis 29 (TD), 23 (GD) and 16 (TA) samples were prepared at the Department of Palynology and Climate Dynamics, University of Göttingen, Germany. Samples of $0.5 \mathrm{~cm}^{3}$ of the raw, cooled sediment was processed with the standard pollen analytical techniques including $\mathrm{HCl}$ treatment and acetolysis (Faegri and Iversen, 1989). Prior to the chemical treatment one Lycopodium tablet was added to each sample in order to calculate the pollen concentration $\left(\right.$ grains $/ \mathrm{cm}^{3}$ ). The residue of each sample was mounted on slides with glycerol and at least 200 pollen grains per slide were counted at $400 \times$ magnification. Identification of pollen and spores was accomplished by reference pictures (APSA Members 2007; Huang, 1972; Roubik and Moreno, 1991; Thanikaimoni, 1987). Pollen diagrams were created using the commercial programme Grapher 5. The total pollen sum was used to calculate percentages of all taxa and bases on all taxa excluding aquatics and spores. The pollen zones were defined using a $50 \%$ and a $10 \%$ threshold of the dominating component (primarily Rhizophora) following studies on pollen abundance in deposits beneath mangrove forests and adjoining communities (Blasco, 1984; Hofmann, 2002; Li et al., 2008; Rowe, 2005; Somboon, 1990). The arrangement of the pollen genera and family was based on their occurrence within the mangrove forest from seaward margin on the right to landward margin on the left (cf. Table 2). Freshwater vegetation families were arranged according to their abundance.

Macroscopic charcoal was preferred over microscopic particles since large charcoal particles are deposited nearby the fire and are not as easily suspended after deposition (Clark, 1988). For macrocharcoal analysis 86 (TD), 23 (GD) and 16 (TA) samples were prepared following the method described in Stevenson and Haberle (2005). For each sample $2 \mathrm{~cm}^{3}$ were used and wet-sieved at $125 \mu \mathrm{m}$ after chemical treatment. The samples of core TD were additionally sieved at $250 \mu \mathrm{m}$ to dispose of large organic remains. The complete remaining fraction was counted at $25 \times$ magnification.

\section{Results}

\section{Sediment characteristics and chronology}

Core TD. The whole core consists of mud with max. 22 wt.\% of material $>63 \mu \mathrm{m}$ (Figure 2). The TC-values vary between $1.1 \mathrm{wt} . \%$ $(45 \mathrm{~cm})$ and $17.9 \mathrm{wt} . \%$ (543 cm, Figure 2). Planktonic foraminifera tests of fresh appearance occur between 571 and $503 \mathrm{~cm}$, at 291 and $276 \mathrm{~cm}$. The radiocarbon ages at 178 and $151 \mathrm{~cm}$ are 6020-6280 and 2790-2950 cal. yr BP, respectively (Table 3).

Core GD. The whole core predominantly consists of mud with $\leq$ $10 \mathrm{wt} . \%$ of very fine to fine sand throughout the core. Grains of coarse sand- to fine gravel-size enveloped by iron(hydr)oxide coatings occur between 100 and $90 \mathrm{~cm}$ (Figure 2). The TC-values range between 0.5 wt. $\%(68 \mathrm{~cm})$ and 4.2 wt. $\%$ (203 cm, Figure 2). The radiocarbon ages at 213,167, 112 and $80 \mathrm{~cm}$ are $6780-6700$, $6290-6410,5310-5470$ and $6300-6440$ cal. yr BP (Table 3). The 


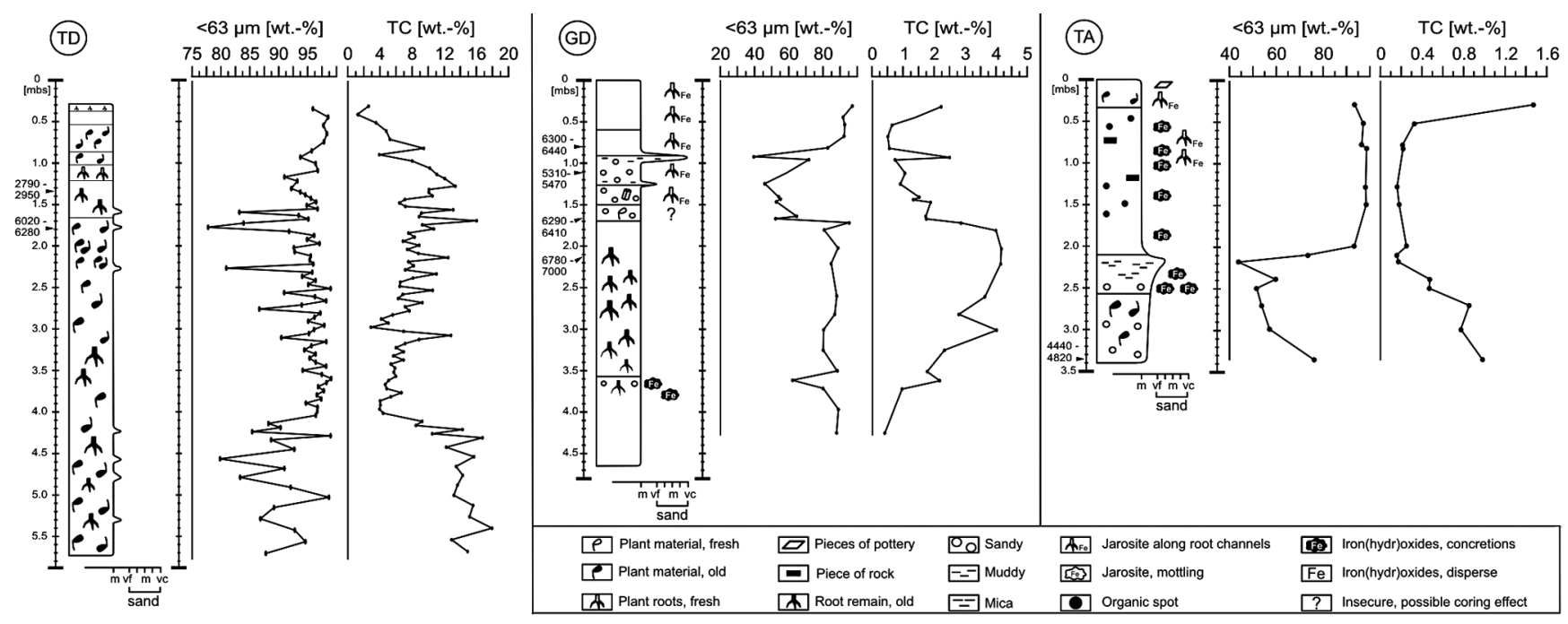

Figure 2. Columnar sections, mud $(<63 \mu \mathrm{m})$ and total carbon contents of cores TD, GD and TA plotted against depth in metres below surface. Calibrated radiocarbon ages are given on the left of each core

age at $80 \mathrm{~cm}$ is older than the underlying one, implying that the uppermost part of the core contains reworked sediment.

Core TA. From 340 to $c .200 \mathrm{~cm}$ the core is composed of either very fine to fine sand (around $218 \mathrm{~cm}$ ) or very sandy mud (50-70 wt. $\%$ mud). The remaining part of the core consists of $>90 \mathrm{wt} . \%$ mud. The TC-values range between 0.2 (major parts of the core) and $1.5 \mathrm{wt}$ \% (top of the core, Figure 2). From 340 to $270 \mathrm{~cm}$ abundant shells and shell fragments from bivalves, gastropods, crustaceans, echinoderms, ostracods and foraminifera (mainly Asterorotalia sp.) are recorded. The radiocarbon age at $335 \mathrm{~cm}$ is 4440-4820 cal. yr BP (Table 3).

\section{Pollen, spore and macro-charcoal records}

The pollen, fern and fungal spore distribution as well as macrocharcoal records are shown in Figures 3, 4 and 5. The occurrence of Pinus pollen in all cores is ambiguous. It is possible that pollen from e.g. Pinus merkusii, a major component of the highland pine forests northeast of the delta (Schmid, 1974), were transported by wind over the long distance to the sites. Hence, the occurrence of Pinus pollen is excluded from the interpretation but added to the diagrams to represent a possible hinterland signal. Sedimentation rates beneath mangroves are highly variable (Woodroffe, 1992) and since erosion cannot be fully excluded, we refrained from evaluating the basal age of the lowermost pollen zones.

The northeastern MRD is known for its potential and actual acid sulphate soils (Husson et al., 2000). During the formation of these soils organic material (including pollen) is consumed in chemical redox processes (J Gröger, U Proske, TJJ Hanebuth, K Hamer and HD Schultz, unpublished data, 2010). The total pollen concentration values of all cores, however, are relatively high, showing that soil formation processes did not strongly affect the palynological signal. Other indicators for postdepositional alterations of the organic material are fungal spores. The abundance of fungal spores can be used as measure for the active decomposition of organic matter in the sediment (e.g. Almeida-Lenero et al., 2005). The abundance of fungal spores, however, is predominantly paralleled by high total pollen concentration values in the records indicating minimal decomposition of pollen by fungi.

\section{Core TD}

Zone TD-I (574 to $\sim 125 \mathrm{~cm}$, early/mid Holocene to $2790-2950$ cal. yr BP). The lowest zone in the core shows the predominance of Rhizophora pollen (71-96\%) with minor contributions from Ceriops $(\leq 10 \%)$, Kandelia $(\leq 6 \%)$ and Bruguiera $(\leq 3 \%)$. Additionally, the presence $(\leq 5 \%)$ of other pollen of the mangrove community and freshwater vegetation is recorded. Values of total pollen and fungal spore concentration are on a moderate to low level. Macrocharcoal shows slightly higher values at the base and low values throughout the middle and the upper part of the zone. A marked decline of Rhizophora pollen (36\%) occurs at $260 \mathrm{~cm}$ paralleling an increase in pollen of Arecaceae (16\%), Fabaceae (9\%), Elaeocarpaceae $(7 \%)$ as well as total pollen and fern spore concentration.

Zone TD-2 ( $/ 25$ to $\sim 55 \mathrm{~cm}, 2790-2950$ to II $50-1200 \mathrm{cal}$. yr BP). The second zone is characterised by a decrease in Rhizophora pollen percentages (11-32\%) with marked increases in pollen of Bruguiera $(\leq 7 \%)$, Arecaceae $(\leq 23 \%)$, Cyperaceae $(\leq 11 \%)$, Fabaceae $(\leq 9 \%)$ and Poaceae $(\leq 7 \%)$. Other pollen of the mangrove community and freshwater vegetation are present $(\leq 5 \%)$. Values of total pollen, fungal and fern spore, Acrostichum sp., Polypodiaceae and macro-charcoal concentration show an abrupt increase and remain on a high or moderate level.

ZoneTD-3 ( 55 cm to top, I I 50- I 200 cal.yr BP to modern). The uppermost zone marks the complete disappearance of pollen of the mangrove community. Freshwater vegetation is dominated by pollen of Arecaceae (29\%), Poaceae (20\%), Cyperaceae (15\%), Fabaceae $(6 \%)$ and Burmannia $(7 \%)$. Values of total pollen, fungal and fern spore concentration are low whereas Polypodiaceae show an increase. Macro-charcoal values further increase to the highest value in the core.

\section{Core GD}

From 465 to $355 \mathrm{~cm}$ core depth the sediment contained no pollen, spores and macro-charcoal. However, no information about the Holocene palaeoenvironment is lost since this part of the core represents the Late Pleistocene soil surface. 


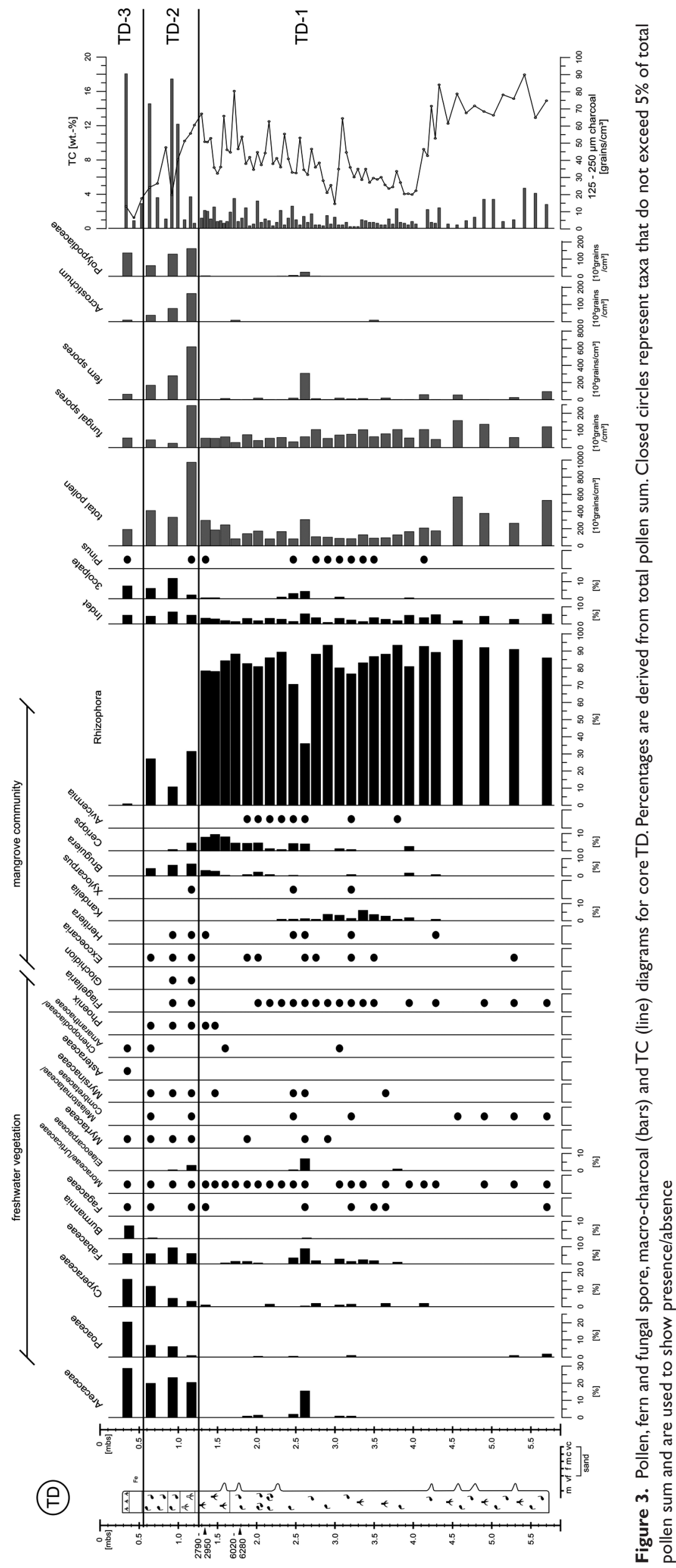




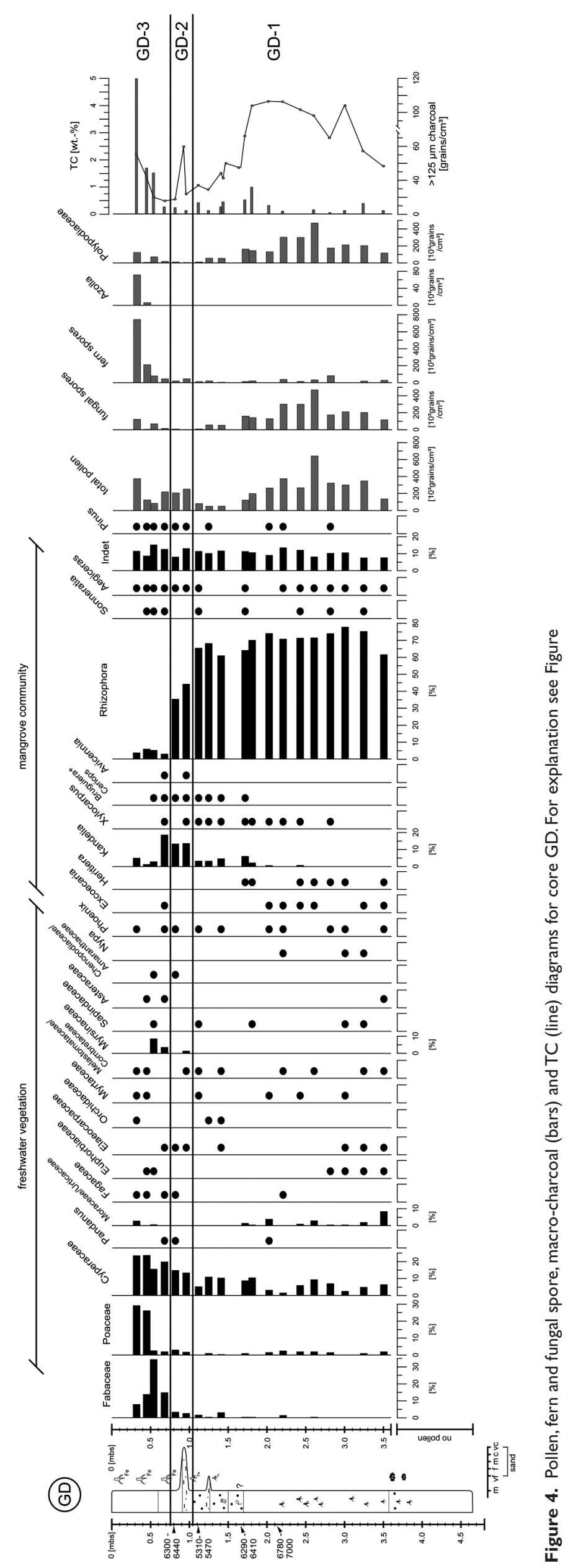




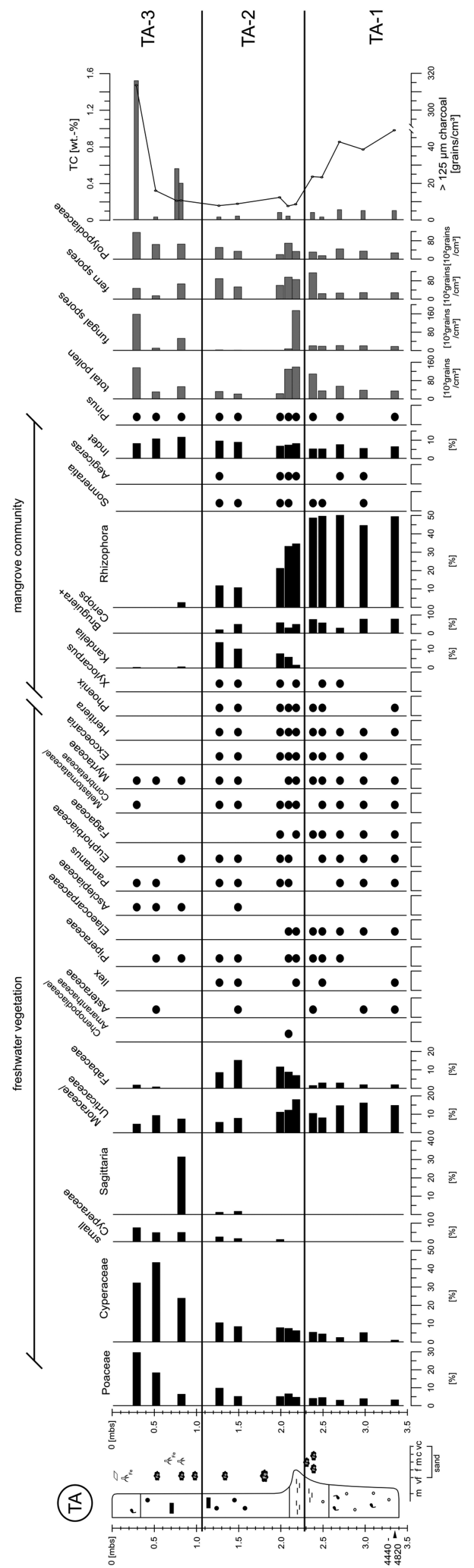

Zone GD-I (355 to $105 \mathrm{~cm}$, early/mid Holocene to 53 I 0-5470 cal. yr BP). The lowermost zone is dominated by pollen of Rhizophora (78-61\%) with minor contributions from Kandelia $(\leq 6 \%)$, Cyperaceae $(\leq 11 \%)$ and Poaceae $(\leq 3 \%)$. Values of total pollen, fungal spore and Polypodiaceae concentration show an increase towards $255 \mathrm{~cm}$ where they reach a maximum and subsequently decrease towards the top of the zone. Fern spore concentration and macro-charcoal values are low throughout this zone.

Zone GD-2 ( 105 to $70 \mathrm{~cm}, 5310-5470$ to 3300-3400 cal. yr BP). The second zone marks the gradual decrease of Rhizophora pollen (35-44\%) paralleling an increase in pollen of Kandelia (13\%), Cyperaceae $(\leq 15 \%)$, Fabaceae $(\leq 4 \%)$ and other freshwater vegetation elements. Other pollen of the mangrove community and freshwater vegetation are present $(\leq 5 \%)$. Values of total pollen concentration are on a moderate level, fungal and fern spores, Polypodiaceae and macro-charcoal concentrations are low in this zone.

Zone GD-3 (70 cm to top, 3300-3400 cal. yr BP to modern). The uppermost zone is characterised by the further decline of Rhizophora pollen $(\leq 6 \%)$ and pollen of Kandelia reach the highest value $(18 \%)$ followed by a decrease to very low values $(\leq 5 \%)$ at $\sim 55 \mathrm{~cm}$. Freshwater vegetation mainly represented by pollen of Fabaceae $(\leq 34 \%)$, Poaceae $(\leq 29 \%)$, Cyperaceae $(\leq 24 \%)$ and Myrsinaceae $(\leq 8 \%)$ dominates the record. Values of total pollen, fungal and fern spores, Polypodiaceae and macro-charcoal increase with some reaching their maxima within the record. The occurrence of Azolla spores is recorded at the top of the zone.

\section{Core TA}

Zone TA-I (340 to $230 \mathrm{~cm}, 4440-4820$ to $2950-3300 \mathrm{cal}$. yr BP). The lowermost zone is dominated by pollen of Rhizophora ( $\leq 50 \%)$, Bruguiera and Ceriops $(\leq 8 \%)$. Freshwater vegetation is represented by pollen of Moraceae/Urticaceae $(\leq 16 \%)$, Cyperaceae $(\leq 5 \%)$ and Poaceae $(\leq 4 \%)$. Values of total pollen, fungal and fern spore, Polypodiaceae and macro-charcoal concentration are low.

Zone TA-2 (230 to $\sim 108 \mathrm{~cm}, 2950-3300$ to I500-I $600 \mathrm{cal}$. yr $B P)$. The second zone marks the decrease in pollen of Rhizophora $(\leq 35 \%)$ and Bruguiera and Ceriops $(\leq 6 \%)$. Towards the top of the zone pollen of Kandelia $(\leq 14 \%)$, Moraceae/Urticaceae $(\leq 18 \%)$, Fabaceae $(\leq 15 \%)$, Cyperaceae $(\leq 10 \%)$ and Poaceae $(\leq 10 \%)$ increase whereas Moraceae/Urticaceae show a maximum at the base of the zone. Total pollen and fungal spore concentration values are highest at the base of the zone and decrease towards the top. Fern spores, Polypodiaceae and macro-charcoal concentration values are on a medium to low level throughout.

Zone TA-3 ( 108 to top, 1500-1600 cal. yr BP to modern). The sample at $77 \mathrm{~cm}$ core depth contained no pollen and spores. The uppermost zone is completely characterised by pollen of freshwater vegetation such as Cyperaceae $(\leq 43 \%)$, Poaceae $(\leq 29 \%)$, Sagittaria $(\leq 31 \%)$ and Moraceae/Urticaceae $(\leq 9 \%)$. Total pollen and fungal spore concentration values increase towards the top. Fern spores and Polypodiaceae concentration values remain on a medium to low level throughout. Macro-charcoal concentration shows high values at the base and at the top of the zone. 


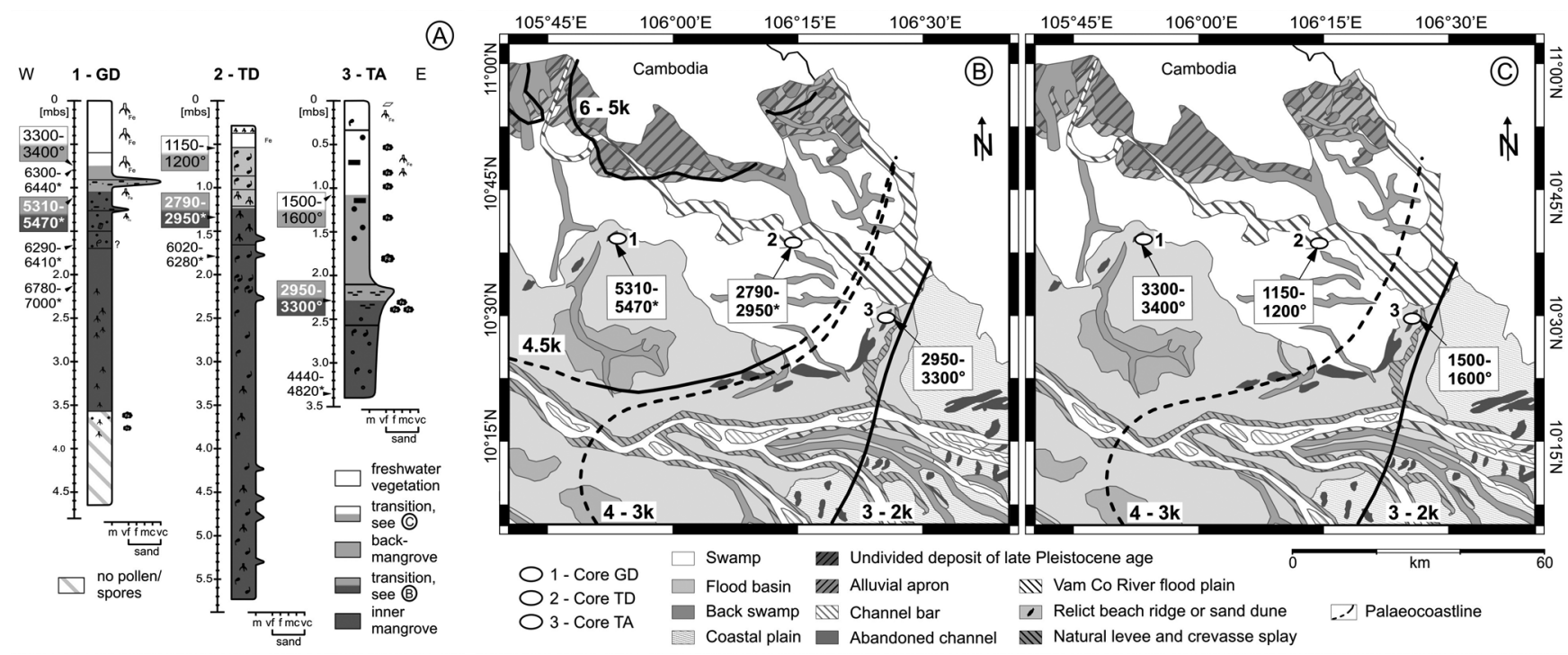

Figure 6. (A) Columnar sections showing interpreted general vegetation zones for all cores. Measured calibrated radiocarbon ages are marked with an asterisk, calculated age spans with an open circle (see text). (B) and (C) Palaeoenvironmental development of the region illustrated by the time spans for the transition inner to back-mangrove (B) and subsequently to freshwater vegetation (C). The base map is simplified and dimmed from Nguyen et al. (2000). The thick, black lines mark the coastlines with corresponding time spans after Nguyen et al. (2000). The coastlines 4.5 and 4-3k yr BP are widely unconfirmed (dashed line, see Nguyen et al. (2000) for details). The asterisk marks time spans directly controlled by calibrated radiocarbon ages, the open circle marks calculated time spans (see text)

\section{Discussion}

The palaeoenvironment in the early to mid Holocene

During the mid-Holocene when sea level was between c. 2.5 and $4.5 \mathrm{~m}$ above present level (Ta et al., 2002a, b), a broad mangrove belt was established along numerous coasts of the Sunda and Sahul shelves (Woodroffe, 1993, 2000; Woodroffe et al., 1985). The Rhizophora-dominated mangrove forests of the northern delta were part of this belt fringing the coastline and river banks as far north as Phnom Penh (Penny, 2006, 2008; Tamura et al., 2009). The palynological records of cores TD and GD indicate that mangrove forests were also widespread throughout the northeastern MRD (zones TD-1 and GD-1, Figures 3, 4 and 6A). High percentages of Rhizophora pollen mark their strong presence at the sites and the occurrence of Avicennia, Sonneratia, Bruguiera, Ceriops, Kandelia and Aegiceras indicate a distinct zonation of these forests. The relatively low macro-charcoal values mark an overall irregular and infrequent, natural burning of the regional vegetation. More intense burning could be mirrored in the slightly elevated charcoal values coinciding with minor abundant Poaceae pollen (1-2\%) in the lowermost c. $0.5 \mathrm{~m}$ of zone TD-1 (Figure 3). A similar signal from northeastern Cambodia has been related to drier conditions leading to frequent burning of the local to regional vegetation between 9300 and $7900 \mathrm{yr}$ BP (Maxwell, 2004).

At sites TD and GD mangrove deposits are thick (4.5 and 2.55 $\mathrm{m}$, respectively, Figure 6A) implying either a fast sediment buildup during the sea-level highstand or the onset of accumulation already during the late stage of the postglacial transgression. Mangrove peat accretion in a thriving forest can keep pace with a 2 to $10 \mathrm{~mm} / \mathrm{yr}$ sea-level rise (Ellison, 2008). The oldest mangrove deposits from southern Cambodia accumulated c. 8000 yr BP (Tamura et al., 2009) when sea level was $c .5 \mathrm{~m}$ below modern level (Tamura et al., 2009). From 8000 to $6000 \mathrm{cal}$. yr BP sea level rose at an average of 3-4 mm/yr, which could have been balanced by sediment accumulation beneath the mangrove forests. Thus mangrove forests probably established already during the early mid-Holocene in the northern parts of the delta and dominated the coastal landscape during the late transgression.

The short-term decline in Rhizophora pollen at $262 \mathrm{~cm}$ in core TD (TD-1, Figure 3) is paralleled by an increase in freshwater taxa (mainly Arecaceae, Fabaceae, Elaeocarpaceae and ferns). An intense fire event in the mangrove forest can be excluded since macro-charcoal concentration is not increased. Various other observations, however, imply a brief and intense disturbance of the site. First, the higher total pollen concentration value at $262 \mathrm{~cm}$ indicates a temporarily lowered sedimentation rate. Second, below the decline in Rhizophora pollen (between 302 and $280 \mathrm{~cm}$ ) the sediment appears chaotic and contrasts the under- and overlying slightly laminated sediments. And third, the samples at 291 and $276 \mathrm{~cm}$ contain fresh and unbroken planktonic foraminifera tests that have not been detected in other samples directly above or below this interval. These features imply a temporary disturbance of the site as it could be expected by a storm- or typhoon-induced flood event. Such a short-term, high-energy event is able to damage the coastal vegetation, transport shallow marine shelf sediments (including foraminifera) landwards and thus produce deposits with the features described above. After the event, the hinterland pollen signal would be enhanced and sedimentation rate would be lowered owing to sparse mangrove presence and thus decreased sediment trapping at the site. Since there are no gap specialists in mangrove communities (Clarke and Kerrigan, 2000), the affected area would be gradually recolonized by species from the surrounding, intact mangrove forest. This recolonization is probably reflected in the stepwise recovery of Rhizophora, the decline of Kandelia and the increase of Avicennia and Ceriops (Figure 3). A similar signal is absent at site GD being either due to its geographical position where the elevated Pleistocene terraces shelter the area from the prevailing northeasterly storms or the sample resolution being too low to detect this decline. 


\section{Palaeoenvironmental development in the late Holocene}

The regional development after c. 4500 cal. yr BP is characterized by the establishment of back-mangrove and freshwater vegetation in the northeastern MRD. By assuming a constant sedimentation rate after the mid Holocene and by using the $2 \sigma$-ranges of the calibrated age data it is possible to calculate time spans for the changes in vegetation where no radiocarbon dates are available (Figure 6A). Two transitions are established for each core: from inner mangrove to back-mangrove (Zone 1 to 2, Figures 3 to 6A) and subsequently to freshwater vegetation (Zone 2 to 3 , Figures 3 to $6 \mathrm{~A}$ ).

At the westernmost site GD the back-mangrove signal is mainly composed of Kandelia, Bruguiera, Ceriops and Avicennia (Figure 4, GD-2) indicating that saltwater influence in the area is limited to flooding during high tide. Other back-mangrove elements such as Phoenix, Excoecaria and Heritiera are present in the region already since the early mid-Holocene but show no increased abundance at this stage. The radiocarbon ages imply that back-mangrove established directly after the mid-Holocene sealevel highstand in the area around site GD which indicates a very fast seaward coastline migration (Figure 6B). However, the uppermost calibrated radiocarbon age shows inversion as a result of sediment mixing or bioturbation in this part of the core and thus leaves the time frame for the development from mangrove to freshwater vegetation in the area around this site unclear.

At site TD the back-mangrove signal is dominated by Ceriops, Bruguiera, Heritiera, Excoecaria, Glochidion, Phoenix and Acrostichum marking the decreasing influence of saltwater in the area around 3000 cal. yr BP (Figures 3 and 6A, TD-2). Increased total pollen and fern spore concentration values indicate a lower sedimentation rate as it is typical for the floodplain environment where sediment is supplied only during the annual summer monsoonal flooding. In this area the back-mangrove established relatively late when the coastline was already $c .30 \mathrm{~km}$ further south (Nguyen et al., 2000 and Figure 6B). To support the mangrove community along the river banks, sufficient seawater must have been transported upstream in the Vam Co Tay River which can be achieved by tidal pumping. In the modern southern MRD this effect is commonly observed and mangroves grow along rivers as far as $90 \mathrm{~km}$ inland today (Hong and San, 1993). In zone TD-2 macro-charcoal values increase rapidly being either due to intense burning of the local, more open vegetation or the beginning of human settling accompanied by fires in the region. The radiocarbon age and the archaeological record for the area imply that this charcoal signal could be linked to ancient settlers but natural fires cannot be fully excluded.

The southernmost site TA shows a generally weak Rhizophora signal implying that the local conditions were not suitable to support mangroves directly in the area around the site. The lowermost zone (Figure 5, TA-1), however, is dominated by the sum of Rhizophora, Bruguiera, Ceriops, Sonneratia and Aegiceras marking a zoned mangrove forest in the general region during the sea-level regression. The coeval strong signal from freshwater forest and grassland/swamp elements such as Moraceae/Urticaceae, Poaceae, Cyperaceae and Fabaceae reflects the geomorphological diversity of the delta plain (Figure 6B,C) and underlines that freshwater vegetation is already common in the area. The representation of a back-mangrove (mainly Kandelia) is weak and probably a result of the conditions in the area that prevented an extensive mangrove development. The change from inner to back-mangrove has been calculated between 2950 and $3300 \mathrm{cal}$. yr BP and thus has to be viewed with caution (Figure 6B). Around 3000 to $2000 \mathrm{yr}$ BP the reconstructed position of the coastline is just south of the site (Nguyen et al., 2000), which indicates either a very fast vanishing of the inner mangroves or the calculated age span is too old.

At all sites, the subsequent shift from back-mangrove to freshwater vegetation is consistent with the coastline evolution (Figure $6 \mathrm{C}$ ). The general, typical signature of swamp vegetation is dominated by Cyperaceae, Fabaceae and Poaceae. At site GD the transition from back-mangrove to freshwater around 3300-3400 cal. yr BP is problematic owing to the inversion of the uppermost two radiocarbon ages. Nevertheless the freshwater vegetation shows a varying composition with Myrsinaceae adding a forest to shrub land signal and Azolla spores, occurring in the uppermost sample and being associated with modern rice cultivation (Schmid, 1974), mark the establishment of agriculture in the area around this site. The simultaneous increase in macro-charcoal particles underlines that modern settlers were reshaping the environment of the site.

Arecaceae and the freshwater swamp marker Burmannia are remarkably common at site $\mathrm{TD}$, indicating that the river floodplain is a moist habitat throughout the year (Schmid, 1974). High amounts of macro-charcoal particles imply the presence of settlers in the area and the rise in Arecaceae pollen could be linked to an active cultivation of palms.

Site TA records a short-term occurrence of Sagittaria, an aquatic to riparian genus. It seems that a small, temporary lake or channel established in the vicinity of the Vam Co Tay River, providing the temporary habitat for this genus. However, this lake or channel prevailed not long enough to support full aquatic vegetation. Similar to the two other cores a strong macro-charcoal signal documents the increased human activity in the region.

\section{Conclusions}

The palaeoenvironmental reconstruction of the northeastern MRD underlines the dynamics of the delta development since the mid Holocene. An inner mangrove community moved with the seaward migrating shoreline and was gradually replaced by backmangroves. The back-mangrove forests seem to have prevailed for a long time especially along rivers that supplied brackish water. Finally, diverse freshwater vegetation developed on the MRD plain. Natural burning of the regional vegetation is recorded in the low abundance of macro-charcoal particles in the lower parts of all records whereas the high values in the uppermost parts of the records document the modern human activity.

Furthermore this study shows that palynological techniques, being optimised for swamp and lake deposits, are also applicable to dynamic delta deposits that have been subjected to soil formation processes. The results demonstrate the importance of palynological studies to fully assess a delta's palaeoenvironmental development. This palaeoenvironmental reconstruction also offers the opportunity for archaeological researchers to add new information to the understanding of ancient settlements in the region.

\section{Acknowledgements}

UP thanks Stijn De Schepper and Lydie Dupont for providing a microscope and other equipment, Simon Haberle for helping with pollen identification and Ian Kilmister for all manner of assistance during the Ph.D. research. UP is grateful for the support by the APSA internship programme. We would like to thank all the local Vietnamese authorities who supported us during our fieldwork. We are grateful to two 
anonymous reviewers whose constructive comments helped to improve the manuscript. This study is part of the DFG-funded project HA4317 2-1 and is a MARUM-publication.

\section{Funding}

Funding was provided by the Deutsche Forschungsgemeinschaft - DFG.

\section{References}

Almeida-Lenero L, Hooghiemstra H, Cleef AM and van Geel B (2005) Holocene climatic and environmental change from pollen records of lakes Zempoala and Quila, central Mexican highlands. Review of Palaeobotany and Palynology 136(1-2): 92

APSA Members (2007) The Australasian Pollen and Spore Atlas V1.0. Canberra: Australian National University. Available at: http://apsa anu.edu.au/

Biggs D (2003) Problematic progress: Reading environmental and social change in the Mekong Delta. Journal of Southeast Asian Studies 31(1): 77-96.

Biggs D, Miller F, Hoanh CT and Molle F (2009) The Delta Machine: Water management in the Vietnamese Mekong Delta in historical and contemporary perspectives. In: Molle F, Foran T and Käkönen M (eds) Contested Waterscapes in the Mekong Region. London: Earthscan, 203-226.

Blasco F (1984) Climatic factors and the biology of mangrove plants. In: Snedaker SC and Snedaker JG (eds) The Mangrove Ecosystem: Research Methods. Paris: UNESCO, 18-35.

Clark JS (1988) Particle motion and the theory of charcoal analysis: Source area, transport, deposition and sampling. Quaternary Research 30: 67-80.

Clarke PJ and Kerrigan RA (2000) Do forest gaps influence the population structure and species composition of mangrove stands in northern Australia? Biotropica 32(4a): 642-652.

Duc LD (2006) Socialist Republic of Vietnam. International Water Management Institute, $61 \mathrm{pp}$.

Ellison JC (2008) Long-term retrospection on mangrove development using sediment cores and pollen analysis: A review. Aquatic Botany 89(2): 93-104.

Faegri K and Iversen J (1989) Textbook of Pollen Analysis. Chichester: John Wiley \& Sons, $328 \mathrm{pp}$.

Fujimoto K, Umitsu M, Kawase K, Nguyen VL, Ta TKO and Huynh DH (2008) Geomorphological Evolution and Mangrove Habitat Dynamics of the Northern Mekong River Delta and the Dong Nai River Delta. Geomorphological Comparative Research on Natural Disaster Mitigation in the Coastal Regions of Tropical Asia, Phuket, Ho Chi Minh, Pattaya. Department of Geography, Nagoya University, 75-83.

Hofmann C-C (2002) Pollen distribution in sub-recent sedimentary environments of the Orinoco Delta (Venezuela) - An actuopalaeobotanical study. Review of Palaeobotany and Palynology 119: 191-217.

Hong PN (2000) Effects of mangrove restoration and conservation on the biodiversity and environment in Can Gio district, Ho Chi Minh City. In: Field C (ed.) International Workshop Asia-Pacific Cooperation on Research for Conservation of Mangroves, Okinawa, Japan, 26-30 March 2000. Okinawa: The International Society for Mangrove Ecosystems, 14.

Hong PN and San HT (1993) Mangroves of Vietnam. Bangkok: IUCN, $173 \mathrm{pp}$

Hori H (2000) The Mekong: Environment and Development. Tokyo, New York, Paris: United Nations University Press, 398 pp.
Huang T-C (1972) Pollen Flora of Taiwan. National Taiwan University Botany Department Press, 297 pp.

Husson O, Verburg PH, Phung MT and Mensvoort MEFV (2000) Spatial variability of acid sulphate soils in the Plain of Reeds, Mekong Delta, Vietnam. Geoderma 97: 1-19.

Kono Y (2001) Canal development and intensification of rice cultivation in the Mekong Delta: A case study in Cantho Province, Vietnam. South East Asian Studies 39(1): 70-85.

Li Z, Zhang Z, Li J, Zhang Y, Li Z, Liu Let al. (2008) Pollen distribution in surface sediments of a mangrove system, Yingluo Bay, Guangxi, China. Review of Palaeobotany and Palynology 152: 21-31.

Maxwell AL (2004) Fire regimes in north-eastern Cambodian monsoonal forests, with a 9300-year sediment charcoal record. Journal of Biogeography 31: 225-239.

Mekong River Commission (2005) Overview of the Hydrology of the Mekong Basin. Vientane: Mekong River Commission, 73 pp.

Nguyen HC (1993) Geo-pedological study of the Mekong Delta. Southeast Asian Studies 31(2): 158-186.

Nguyen VL, Ta TKO and Tateishi M (2000) Late Holocene depositional environments and coastal evolution of the Mekong River Delta, Southern Vietnam. Journal of Asian Earth Sciences 18: 427-439.

Nguyen VS, Vo-Tong X and Tran AP (1998) History and future of farming systems in the Mekong Delta. In: Xuan V-T and Matsui S (eds) Development of Farming Systems in the Mekong Delta of Vietnam. Ho Chi Minh City: JIRCAS, CTU and CLRRI, 16-80.

Penny D (2006) The Holocene history and development of Tonle Sap, Cambodia. Quaternary Science Reviews 25: 310-322.

Penny D (2008) The Mekong at climatic crossroads: Lessons from the geological past. Ambio 37(3): 164-169.

Proske U, Hanebuth TJ, Gröger J and Diệm, BP (2010) Late Holocene sedimentary and environmental development of the northern Mekong River Delta, Vietnam. Quaternary International in press.

Roubik DW and Moreno JE (1991) Pollen and Spores of Barro Colorado Island. Missouri: Missouri Botanical Garden, $270 \mathrm{pp}$.

Rowe C (2005) A Holocene history of vegetation change in the western Torres Strait region, Queensland Australia. School of Geography and Environmental Science, Monash University, Clayton. Unpublished $\mathrm{PhD}$ thesis.

Schmid M (1974) Végétation du Viet-Nam. Paris: ORSTOM, 243 pp.

Schmid M (1989) Vietnam, Kampuchea and Laos. In: Campbell DG and Hammond HD (eds) Floristic Inventory of Tropical Countries. New York: New York Botanical Garden, 83-90.

Somboon JRP (1990) Palynological study of mangrove and marine sediments of the Gulf of Thailand. Journal of Southeast Asian Earth Sciences 4(2): 85-97.

Sterling EJ, Hurley MM and Minh LD (2006) Vietnam: A Natural History. New Haven and London: Yale University Press, 423 pp.

Stevenson J and Haberle S (2005) Macro Charcoal Analysis: A Modified Technique used by the Department of Archaeology and Natural History. Canberra: Australian National University, 9 pp. Available at: http://palaeoworks.anu.edu.au/paltr05.pdf

Stuiver M and Reimer PJ (1993) Extended ${ }^{14} \mathrm{C}$ data base and revised CALIB 3.0 ${ }^{14} \mathrm{C}$ age calibration program. Radiocarbon 35(1): 215-230.

Ta TKO, Nguyen VL, Tateishi M, Kobayashi I and Saito Y (2002a) Sediment facies and Late Holocene progradation of the Mekong River Delta in Bentre Province, southern Vietnam: An example of evolution from a tide-dominated to a tide- and wave-dominated delta. Sedimentary Geology 152: 313-325.

Ta TKO, Nguyen VL, Tateishi M, Kobayashi I, Tanabe S and Saito Y (2002b) Holocene delta evolution and sediment discharge of the 
Mekong River, southern Vietnam. Quaternary Science Reviews 21: 1807-1819.

Tamura T, Saito Y, Sieng S, Ben B, Kong M, Sim I et al. (2009) Initiation of the Mekong River delta at $8 \mathrm{ka}$ : Evidence from the sedimentary succession in the Cambodian lowland. Quaternary Science Reviews 28: 327-344.

Tanaka K (2001) Agricultural development in the broad depression and the Plain of Reeds in the Mekong Delta: Conserving forest or developing rice culture? Southeast Asian Studies 39(1): $137-150$.

Thanikaimoni G (1987) Mangrove Palynology. UNDP/UNESCO and Institut Français de Pondichéry, 100 pp.

Tomlinson PB (1994) The Botany of Mangroves. Cambridge: Cambridge University Press, $419 \mathrm{pp}$.

Woodroffe C (1992) Mangrove sediments and geomorphology. In: Robertson AI and Alongi DM (eds) Tropical Mangrove Ecosystems.
Washington DC: American Geophysical Union, Coastal and Esuarine Series 41, 7-41.

Woodroffe CD (1993) Late Quaternary evolution of coastal and lowland riverine plains of Southeast Asia and northern Australia: An overview. Sedimentary Geology 83: 163-175.

Woodroffe CD (2000) Deltaic and estuarine environments and their Late Quaternary dynamics on the Sunda and Sahul shelves. Journal of Asian Earth Sciences 18: 393-413.

Woodroffe CD, Thom BG and Chappell J (1985) Development of widespread mangrove swamps in mid-Holocene times in northern Australia. Nature 317: 711-713.

Woodroffe CD, Nicholls RJ, Saito Y, Chen Z and Goodbred SL (2006) Landscape variability and the response of Asian megadeltas to environmental change. In: Harvey N (ed.) Global Change and Integrated Coastal Management: The Asia-Pacific Region. Dordrecht: Springer, 277-314. 